\title{
26th December 2004 Great Sumatra-Andaman Earthquake: co-seismic and post-seismic motions in northern Sumatra
}

\author{
Jean-Claude Sibuet ${ }^{a}$, Claude Rangin ${ }^{b}$, Xavier Le Pichon $^{b}$, Satish Singh ${ }^{c}$, Antonio Cattaneo ${ }^{a}$, \\ David Graindorge ${ }^{a}$, Frauke Klingelhoefer ${ }^{a}$, Jing-Yi Lin ${ }^{a}$, Jacques Malod ${ }^{a}$, Tanguy Maury ${ }^{a}$, \\ Jean-Luc Schneider", Nabil Sultan ${ }^{a}$, Marie Umber ${ }^{a}$, Haruka Yamaguchi ${ }^{\mathrm{a}}$ and the "Sumatra \\ aftershocks" team
}

\begin{abstract}
${ }^{a}$ Ifremer Centre de Brest, B.P. 70, 29280 Plouzané cedex, France
${ }^{b}$ Collège de France, Chaire de Géodynamique and CNRS CEREGE, Europôle de l'Arbois, BP 80, 13545 Aix en Provence, France

${ }^{c}$ Institut de Physique du Globe de Paris, 4 Place Jussieu, Tour 14-15, 5th Floor, 75252 Paris cedex 05, France

${ }^{\mathrm{d}}$ Institut Universitaire Européen de la Mer, Place Nicolas Copernic, 29280 Plouzané, France

eUniversité Bordeaux 1, Observatoire Aquitain des Sciences de l'Univers, Département de Géologie et Océanographie, Avenue des Facultés, 33405 Talence cedex, France

Institute for Research on Earth's Evolution, Japan Agency for Marine-Earth Science and Technology, Natsushima-cho 2-15, Yokosuka, 237-0061, Japan
\end{abstract}

*: Corresponding author: Jean-Claude Sibuet, Ifremer Centre de Brest, B.P. 70, 29280 Plouzané cedex, France, icsibuet@ifremer.fr, Ph. (33) 2984845 20, mobile (33) 662124520

\begin{abstract}
:
Trench-parallel thrust faults verging both landward and seaward were mapped in the portion of wedge located between northern Sumatra and the Indian-Indonesian boundary. The spatial aftershocks distribution of the 26th December 2004 earthquake shows that the post-seismic motion is partitioned along two thrust faults, the Lower and Median Thrust Faults, the latter being right-laterally offset by a $\mathrm{N}-\mathrm{S}$ lower plate fracture zone located along the $93.6^{\circ} \mathrm{N}$ meridian. Between February 2005 and August 2005 , the upper plate aftershock activity shifted from southeast of this fracture zone to northwest of it, suggesting that the lower plate left-lateral motion along the fracture zone may have induced a shift of the upper plate post-seismic activity along the Median Thrust Fault. Based on swath bathymetric and $3.5 \mathrm{kHz}$ data, co-seismic deformations were weak close to the trench. Joint seismic-geodetic determination of slip distribution and time arrivals and heights of tsunami waves suggest that the coseismic slip was maximum along a portion of the Upper Thrust Fault located north of the Tuba Ridge, suggesting that the Upper Thrust Fault might be a splay fault originated at the interplate fault plane. As the Upper Thrust Fault is steeper than the slab, the vertical motion of the adjacent Outer Arc and overlying water is much larger compared to the one resulting from slip on the megathrust alone, increasing tsunamogenic effects.
\end{abstract}

Keywords: 2004 Sumatra-Andaman earthquake; aftershocks; co-seismic rupture; active thrust faults 


\section{Introduction}

The $26^{\text {th }}$ December $2004 M w=9.2$ great Sumatra-Andaman earthquake ruptured the Sumatra and Sunda subduction zones over a length of $1300 \mathrm{~km}$ and generated the most deadly tsunami in the historic record. Teleseismically well-recorded earthquakes occurring in this region during the 19182005 period were relocated by Engdahl et al. [1]. Prior to the 2004 earthquake, seismicity occurred downdip along the interplate zone at depths greater than $35 \mathrm{~km}$, with a quasi-absence of seismicity trenchward [1, 2] (Fig. 1a). The co-seismic slip distribution of the Sumatra-Andaman earthquake has been estimated from seismic waves [2, 3], static offsets [4-6], and joint seismic-geodetic data [7]. Most of the co-seismic slip occurred trenchward of prior seismicity and was close to its maximum value of $\sim 20 \mathrm{~m}$ offshore NW Sumatra $[3,5]$ where the tsunami devastated the coast along $\sim 300 \mathrm{~km}$ causing 170,000 of the 230,000 tsunami deaths. Most of the aftershock activity is shallower than $35 \mathrm{~km}$ and located trenchward in areas where previous seismicity was absent [1] (Fig. 1b). However, many aftershocks are also observed between 35 and $75 \mathrm{~km}$, in particular in the northern Sumatra area (Fig. 1b). Therefore, the rupture of the northern Sumatra area seems to present specific characteristics during the northward propagation of the 2004 earthquake.

To understand the reason why the co-seismic slip and tsunami amplitudes were so high in this region, we performed the "Sumatra Aftershocks" cruise (R/V Marion Dufresne, Jakarta, July 15 - Colombo, August 9,2005 ) in order to establish the geodynamical context of the 2004 earthquake and to record the aftershock activity. We selected an area encompassing the whole subduction system from the Wharton Basin to northeast of the Sumatra Fault and located between northern Sumatra and the Indonesia/India water limit. Twenty ocean bottom seismometers (OBSs) were deployed and recorded the local seismicity during 12 days. During the recording period, a $370 \times 75 \mathrm{~km}$ stripe was fully surveyed with a Seafalcon 11 MBES swath-bathymetric system (the bathymetric grid will be available at http://www.ifremer.fr/drogm/Realisation/carto/Indien/Sumatra/index.htm) and a $3.5 \mathrm{kHz}$ mud-penetrator (Fig. 2).

\section{Geodynamic context}

Offshore northern Sumatra, the motion is close to the Australia/Sunda motion [8], that is about 47 $\mathrm{mm} / \mathrm{yr}$ to $\mathrm{NOO4}^{\circ}$ [9]. The focal mechanism of the $26^{\text {th }}$ December 2004 great Sumatra-Andaman earthquake shows that partitioning due to the obliquity of the subduction is complete, because the coseismic motion is perpendicular to the trench, along $N 039^{\circ}$ [2]. This gives $38.5 \mathrm{~mm} / \mathrm{yr}$ for the convergent motion perpendicular to the trench and $29.5 \mathrm{~mm} / \mathrm{yr}$ for the right-lateral motion parallel to the trench. The motion along the right-lateral Sumatra Fault is estimated to be about $25 \mathrm{~mm} / \mathrm{yr}$ in northernmost Sumatra [10]. This suggests that at most $5 \mathrm{~mm} / \mathrm{yr}$ are absorbed by dextral deformation within the wedge [11].

Northwest of Sumatra Island, the Sumatra Fault system extends in a $~ 50-\mathrm{km}$ wide dextral shear band, which continues at sea in the northern part of the bathymetric survey (Fig. 2). Aligned volcanoes suggest that the northern branch of the system, which is named the Sumatra Fault by Sieh and Natawidjaja [10] is the most recent active segment as summarized by Curray [12]. In the Aceh forearc basin, fossil linear faults parallel to the Sumatra Fault (Fig. 2), sometimes showing a compressive component, were identified in its southern portion [13] (Figs 2 and 3). Along the northeastern slope of the Outer Arc, southwest of the Aceh Basin, a festoon of discontinuous strike-slip faults was observed and corresponds to the possible southern extension of the West Andaman Fault (Fig. 3). To the northwest, this dextrally wrenched system merges with the Sumatra Fault system that then proceeds toward the Andaman Sea. To the southeast, the connection of the Sumatra Fault with the Mentawai Fault located north of Simeulue Island (e.g. [13]) or with a former plate boundary located south of Simeulue Island [12] is still unclear. Even if two strike-slip aftershocks occurred close to the West Andaman Fault in the days following the 26 December event [14], and if the two Sumatra and West Andaman fault systems are considered as geologically active systems, they were not active during the 2004 earthquake. Consequently, the stress is still accumulating along the two Sumatra and West Andaman fault systems and one of the two systems at least might break in the future.

The wedge, located between the tectonic front and the broad 40-50 km wide Outer Arc adjacent to the Aceh forearc basin, is 130-km wide (Fig. 2) [15]. Most of the wedge is at a mean depth of $1.5 \mathrm{~km}$ and consists of a series of sigmoidal ridges and troughs that formed several piggy-back basins (Fig. 3). Most of the piggy-back basins are bordered by reverse faults and thrusts with double vergency as 
shown in figures 4 and 5 . About 30 of such thrust faults oriented N340 (parallel to the trench) with both seaward and landward vergences are imaged in the swath-bathymetric (Figs 2 and 3 ) and 3.5 $\mathrm{kHz}$ data. The sigmoidal shape of ridges and troughs is the signature of some amount of distributed dextral wrenching within the wedge. Post-seismic focal mechanisms related to the 2004 Sumatra earthquake (Fig. 1d) as well as interseismic focal mechanisms (Fig. 1c) show several upper plate earthquakes with a right-lateral strike-slip motion trending N-S to $\mathrm{N} 010^{\circ}$ within the wedge suggesting that the structurally observed distributed dextral wrenching would have to be attributed to non-elastic interseismic motion.

The presence of seismically active thrust faults was established by the OBS recording of aftershocks [16]. For Araki et al. [16], these thrust faults might be splay faults in the sense of Park et al. [17], that is thrust faults originating at or near the décollement and propagating to the surface through the upper plate. Deep elongated depressions observed in the bathymetry and $3.5 \mathrm{kHz}$ data mark the outcrops of such thrust faults. This is the case for the intense folding observed within the main piggy-back basin adjacent to the Outer Arc and associated deformations observed on $3.5 \mathrm{kHz}$ data (Figs 4 and 5) that suggest the existence of a major thrust fault (Upper Thrust Fault in Fig. 3) located beneath the Outer Arc and emerging S-W of it (Figs. 2 and 3). However, neither the detailed bathymetry nor the $3.5 \mathrm{kHz}$ sub-bottom data can tell us if they are splay faults and if one or several of them were active during the 2004 earthquake. In the frontal part of the wedge, where the water depth drops from 1 to $4 \mathrm{~km}$ in less than $20 \mathrm{~km}$, a ROV exploration [18] suggests that the most seaward thrust fault identified within the Japanese OBS survey may indeed emerge at the base of a giant anticline-like feature, characterized by a very steep southwest-facing wall with large erosional scarps. This wall is bounded at its base by a thrust fault (Major Thrust Fault in Figs 2, 6 and 7a). Thus, the post-seismic deformation in the wedge may have been distributed along several thrust faults throughout the wedge although we have no direct proofs that they were active during the main shock. The four major thrust faults identified from swath bathymetric and $3.5 \mathrm{kHz}$ data are underlined in Figures 2, 3 and 6.

The explored segment of subduction zone is located above the diffuse India/Australia plate boundary identified between the Investigator Fracture Zone $\left(98^{\circ} \mathrm{E}\right)$ and the Ninety East Ridge [8]. The south to north velocity vector of the Australia plate with respect to the India plate determined in this zone progressively decreases westward across this diffuse boundary from about $1 \mathrm{~cm} / \mathrm{yr}$ to zero [8]. This vector is parallel to the direction of the mapped oceanic fracture zones in the central Wharton Basin [19], which can be traced in direction of the Sunda Trench by using the free-air gravity map [20] and the trends of the detailed magnetic anomaly map [21] (Fig. 1a). Thus, earthquakes occurring within this stripe display N-S left-lateral strike-slip mechanisms (Harvard CMT focal mechanisms), which reactivate old fracture zones (e.g. Figs $1 \mathrm{c}$ and d).

Seismic profiles do not show the emergence of the interplate fault plane [22] and the Sunda Trench is not marked in the bathymetry (Figs 2 and 6). Seaward of the wedge, several $\mathrm{N}-\mathrm{S}$ to $\mathrm{N} 010^{\circ}$ trending lineaments with several tens meters vertical offsets were identified on $3.5 \mathrm{kHz}$ profiles in the oceanic domain adjacent to the Sunda Trench [23, 24] (e.g. Figs 8 and 9). In particular, a 50-km long N-S trending lineament with a vertical offset of $10-30 \mathrm{~m}$ was identified near $93^{\circ} \mathrm{E}$, in the prolongation of the main westward $\mathrm{NO}^{\circ}$ fracture zone identified in the Central Wharton Basin by Deplus et al. [19] (Fig. 1a). Earthquakes with left-lateral strike-slip motion occurred in the close vicinity of this fracture zone during the interseismic (two focal mechanisms in Fig. 1c) and post-seismic periods (two focal mechanisms in Fig. 1d). Even if the oceanic crust close to the Sunda Trench is overlain by $\sim 3 \mathrm{~km}$ of sediments $[25,26]$, the fact that the seafloor is vertically offset by $10-30 \mathrm{~m}$ faults indicates a significant basement deformation related to left-lateral strike-slip faulting with a normal component $[23,24]$ as shown by Profile D (Fig. 9). This deformation is probably associated with the morphological expression of the underlying oceanic fracture zones. The subduction of the fracture zone basement ridges and troughs indents and controls the morphology of the toe of the prism (Fig. 6). $3.5 \mathrm{kHz}$ data also evidences N-S trending landward thrusting and folding of the frontal part of the wedge. Thus, we attribute the deformation of the frontal part of the wedge with re-entrants compatible with a dextrally wrenched tectonic front to the obliquity of the subducting N-S oriented lower plate basement features with the $\mathrm{N} 340^{\circ}$ sedimentary features and thrust faults of the wedge.

In the study area, the signs of tectonic activity linked to the 2004 earthquake and located at the toe of the prism are weak and restricted to small-scale fault-related features and minor landslides [27] (Fig. 6). For example, dives in a small 20-m deep depression (the ditch) that runs parallel with the base of a 12-km long scarp along the toe of the prism show it was an active feature [22]. A detailed study of the minor landslide imaged in Figure 7a shows that it was in fact the result of three consecutive phases of failure, the last one being relatively minor. Coring on the slope located close to the landslide indicates the existence of remolded sediment. The in-situ pore pressure monitoring using a piezometer at the same site shows that an excess pore pressure was generated by a recent event. Sultan et al. [28] 
demonstrated that the excess pore pressure was in a transient regime and that its origin was linked to a local deformation of the upper sediment layers generated at the same time than the 2004 earthquake. Consequently, as there is evidence of only small displacements or failures at the frontal part of the wedge at the time of the 2004 earthquake, the co-seismic displacement was minor at the toe of the prism and has to be found landward. This is an unusual situation as the long-term compressive deformation is generally focused at the toe of the prism.

Several N-S oriented valleys not only cut across the whole wedge but apparently dextrally offset the $\mathrm{N} 340^{\circ}$ anticline and syncline features as well as thrust faults of the wedge, giving rise to sigmoidal dextral wrenched features (Figs 3 and $7 \mathrm{~b}$ ). Moderate size earthquakes with N-S right-lateral strike-slip mechanisms have occurred during the interseismic and postseismic periods in the wedge (e.g. Engdahl, 2007). We suggest that this dextral deformation, due to the motion of the upper plate with respect to the lower plate, absorbed a small part of the shear partitioning [11] and was possibly controlled by the topography of the N-S lower plate fracture zone ridges, along which sinistral shear motions were evidenced in the Wharton Basin (Figs 1c and d). Thus, the deformation of the seafloor would be partly related to the co- and post-seismic ruptures related to the 2004 large giant subduction earthquake (in particular the thrust faults in some of the piggy-back basins) and partly to the distributed dextral wrenching across the wedge, during the mostly non-elastic interseismic deformation.

\section{Aftershock activity}

As the aftershock activity decays rapidly with time, it was crucial to set up the OBS instruments with the shortest possible delay after the 2004 earthquake. In order to image the whole subduction system with a better definition than that of the land stations, twenty short-term OBSs were deployed with a mean 40-60 km inter-distance from the Wharton Basin to north of the Sumatra Fault system (Fig. 10a). The distance between instruments is a compromise between the optimum distance to get the best depth determination of earthquakes originated from the slab $(20-30 \mathrm{~km})$ and the optimum distance to get tomographic images of the whole subduction system including the marine portion of the Sumatra Fault system (70-100 km). The pool of OBSs consisted of 15 instruments based on the GEOMAR electronic system and 5 recently developed MicrOBSs [29]. Except for 15-minutes long noisy patches possibly due to ship noise, all the OBSs recorded good hydrophone and three-component seismograms. We identified events recorded on at least 3 OBSs with a 1-D preliminary velocity law determined by inversion of seismic events, which is similar to the one used by Araki et al. [16]. In February-March 2005, a Japanese expedition deployed 17 short-term instruments during 19-22 days in a small area adjacent to our survey [16] (Fig. 10a). As the 1-D velocity laws used in both experiments are similar, we have displayed in the same figure 1100 published hypocenters identified during the first 10 days of the Japanese experiment [16] and 665 hypocenters identified during our experiment (Fig. 10a). The magnitude Md of earthquakes was determined by using the duration of seismic waves [30]. As the depth determination of events located outside of the two OBS networks is poor, we display a cross-section with events located only within the two OBS networks (498 events from our OBS survey). Although earthquakes are not re-located for the moment with a 3-D velocity model and the dispersion of events projected on the cross-section is increased by the horizontal thrust fault bending in the area of the two OBS surveys (Fig 10a), we can emphasize a few important points: 1) At $5.7^{\circ} \mathrm{N}$, there is a marked transition in the distribution of aftershocks not caused by the distribution of seismometers and already noticed by Engdahl et al. [1] at $5.5^{\circ} \mathrm{N}$ (Figs $1 \mathrm{~b}$ and $1 \mathrm{~d}$ ). This transition broadly corresponds to changes in the co-seismic slip distribution (e.g. [7]) (Fig. 1a). South of $5.7^{\circ} \mathrm{N}$, from the Sunda Trench to the Outer Arc, only small magnitude aftershocks developed (Fig $1 \mathrm{~b}, 1 \mathrm{~d}$ and 10), while further landward exists a dense cluster of larger magnitude thrust-fault aftershocks below the Aceh Basin and forearc, between depths of 30 and $55 \mathrm{~km}$. North of $5.7^{\circ} \mathrm{N}$ the situation reverses. The large magnitude earthquakes occur closer to the trench axis, and there are few aftershocks farther than $75 \mathrm{~km}$ from the trench (Fig. 1d).

2) The dip angle of the slab increases from $10^{\circ}$ between the Sunda Trench $(0 \mathrm{~km})$ and $120 \mathrm{~km}$, to 10 $12^{\circ}$ between 120 and $170 \mathrm{~km}$ and to $15-20^{\circ}$ beyond $170 \mathrm{~km}$ (Fig. 10b). From 0 to $170 \mathrm{~km}$ (i.e. beneath the accretionary wedge and Outer Arc), focal mechanisms are mostly in down-dip extension as shown by Araki et al. [16] and by teleseismic mechanisms (Figure 1d). However, the aftershock seismicity is weak between 120 and $170 \mathrm{~km}$ as also attested by the distribution of relocated seismicity [1] between the dates of the Sumatra and Nias events, which shows an absence of seismicity (except 3 earthquakes) in a 50-km wide band sitting astride the Upper Thrust Fault (Fig. 1b). Beyond $170 \mathrm{~km}$, the seismicity notably increases but seems to be located within interplate zone patches, $\sim 30-\mathrm{km}$ in size. Focal mechanisms become dip-slip type as shown by Araki et al. [16] and by the teleseismic 
mechanisms (Figure 1d), which has been interpreted as an ongoing post-seismic slip beneath the Aceh Basin and forearc [16].

3) A cluster of 186 events was identified on the five deepest OBS stations, in the vicinity of the prism toe, complementing the Japanese data, which did not show such events in the first $40 \mathrm{~km}$ landward of the toe of the prism (Fig. 10a). Before relocation, it is difficult to decipher if these events belong to the upper or lower plate, especially in the first $60 \mathrm{~km}$ from the Sunda Trench. However, events in the Wharton Basin belong to the oceanic crust, suggesting that the swarm of events located immediately $\mathrm{N}-\mathrm{E}$ of the trench are related to lower plate post-seismic activity. As the Major Thrust Fault, which might correspond to the outcrop of the main slab décollement, is not significantly post-seismically active, the aftershock cluster of 186 events located on the Major Thrust Fault is probably related to the left-lateral re-activation of the $\mathrm{N}-\mathrm{S}$ trending fracture zone located along the $93.2^{\circ} \mathrm{E}$ meridian [11], which corresponds to the northward prolongation of one of the fractures zones identified by Deplus et al. [19] in the Central Wharton Basin. The $3.5 \mathrm{kHz}$ profile C (Fig. 8) and swath bathymetric data (Fig. 3) show this feature interpreted as a N-S oriented fold with a possible E-W compressive component. Another $3.5 \mathrm{kHz}$ profile (Profile D in Fig. 9) perpendicular to Profile C shows potential N-S left-lateral strike slips in the area of the cluster of 186 events. However, as the $3.5 \mathrm{kHz}$ penetration is only a few tens of meters, seismic profiles are needed to fully resolve this question.

\section{Thrust faults and splay faults}

Within the upper plate, the distribution of aftershocks is concentrated in four areas:

1) In discrete patches localized in the oceanic crust of the Wharton Basin and beneath the frontal part of the accretionary wedge, along the $93.2^{\circ} \mathrm{E}$ fracture zone. Outside these patches, almost no aftershocks are recorded along the Major Thrust Fault, which is imaged in Fig. 10a and more generally S-W of the Lower Trust Fault emergence, between 0 and $60 \mathrm{~km}$.

2) At $70 \mathrm{~km}$, within the shallow part of the wedge at a mean depth of $1.5 \mathrm{~km}$, the cloud of aftershocks may indicate a distributed deformation. However, as Araki et al. [16], we suggest the presence of an active thrust fault. Here, the precision in the depth determination of hypocenters is sufficient to discriminate between earthquakes belonging to the upper and lower plates. In plane view, aftershocks are located N-E of the trace of the Lower Thrust Fault. The active portion of the Lower Thrust Fault starts in the southeast at its intersection with the $93.6^{\circ} \mathrm{E} \mathrm{N-S}$ valley (Figs $7 \mathrm{~b}$ and 10 ). To the northwest, seismic events continues northwest of our survey until $5.7^{\circ} \mathrm{N}$, following a northerly direction already underlined by a bathymetric trend in the Sandwell and Smith [20] map.

3) At $110 \mathrm{~km}$, the $200-\mathrm{km}$ long elongated cluster of seismic events begins south of the location of the Japanese network $\left(94.4^{\circ} \mathrm{E}\right)$ and disappears at $5.7^{\circ} \mathrm{N}$. As Araki et al. [16], we suggest the presence of a second active $\mathrm{N} 340^{\circ}$ oriented thrust fault (Median Thrust Fault) well imaged in crosssection and plane view (Fig. 10). We observed a shift in the post-seismic activity from S-E of the $93.6^{\circ} \mathrm{E} \mathrm{N}-\mathrm{S}$ valley (Figs 3 and $7 \mathrm{~b}$ ) at the time of the Japanese survey (February 2005) to N-W of this feature at the time of our survey (August 2005). This is not an artifact as both OBS pools recorded earthquakes well outside their networks. Even if the depth determination of seismic events is poor, some of them, located between 80 and $130 \mathrm{~km}$, definitely belong to the underlying oceanic crust (Fig. 10b). The dense but diffuse seismic activity observed in the lower plate and spatially along the N-S $93.6^{\circ} \mathrm{E}$ feature, between $4.3^{\circ} \mathrm{N}$ and $5.1^{\circ} \mathrm{N}$, suggests that it is a re-activated portion of fracture zone which may act as an asperity for the northwestward jump of the aftershock activity along the Median Thrust Fault between February and August 2005.

4) A hypothetical splay fault (Upper Thrust Fault) that may rise from the slab break at $170 \mathrm{~km}$ and outcropping southwest of the Outer Arc has been suggested by Araki et al. [16], though only a small number of upper plate events were recorded. This hypothetical splay fault crops out where we have identified a major thrust fault on the basis of detailed bathymetric and $3.5 \mathrm{kHz}$ data. Very recent active compressive features are shown on profiles A and B (Figs 4 and 5) located in Fig. 3. A pop up feature and small-elongated tilted basins are observed within the piggy-back basin (Fig. 4). Further northwest in the same piggy-back basin, numerous seaward vergence thrust faults show signs of a recent tectonic activity (Fig. 5). Small thrust faults between $19 \mathrm{HO}$ and $19 \mathrm{H} 11$ are testimonies of such a recent tectonic activity within a gently folded sub-basin. On the basis of a careful examination of all $3.5 \mathrm{kHz}$ profiles, we suggest that the Upper Thrust Fault, which is not post-seismically active, was active in the recent past. 


\section{Discussion and conclusion}

From the careful examination of the aftershock activity, two post-seismic active thrust faults were identified (Lower and Median Thrust Faults in solid red lines) and two other thrust faults are not postseismically active (Major and Upper Thrust Faults in dashed red lines, Fig. 10). Figure 11c summarizes the distribution of post-seismic active features: dip-slip along the interplate zone beneath the Aceh basin and the deeper part of the forearc, and down-dip extension beneath the accretionary wedge with the presence of two thrust faults branching on the interplate zone. The two swarms of events located in the frontal part of the wedge and along the $93.6^{\circ} \mathrm{E}$ meridian suggest that this aftershock activity is linked to left-lateral strike slip motions along two fracture zones located at $93.2^{\circ} \mathrm{E}$ and $93.6^{\circ} \mathrm{E}$ longitude. Thus, the reactivation of two lower plate fracture zones triggered by the 2004 earthquake, or due to the westward decrease of the velocity vector in the diffuse area of the Australia/India plate boundary, influences the distribution of the aftershock activity within the accretionary wedge. By analogy, we suggest that the other N-S valleys identified in the swath bathymetric data (Figs 2, 3, 6 and 7) may be associated with underlying lower plate fracture zones.

Before the 2004 earthquake, the seismicity was restricted to northeast of the Upper Thrust Fault and no teleseismic earthquakes were recorded below the accretionary wedge (Fig. 1a). Except if there is some aseismic creep within the accretionary wedge, the locked zone is located beneath the accretionary wedge, southwest of the Upper Thrust Fault, which may be the landward boundary of the locked zone. Therefore, the Upper Thrust Fault seems to be a major upper plate feature but we have no indication that it played a significant role during the 2004 Sumatra earthquake.

The detailed joint seismic-geodetic determination $[5,7]$ shows that west of Andaman Islands the coseismic slip occurred trenchward of the prior seismicity and as far as the trench (Fig. 1a). In contrast, between Simeulue Island $\left(2.5^{\circ} \mathrm{N}\right)$ and south of Nicobar Island $\left(6^{\circ} \mathrm{N}\right)$, the co-seismic slip curves overlap the prior seismicity and the co-seismic slip becomes null somewhere between the Median and Upper Thrust Faults (Fig. 1a), suggesting that no co-seismic motion occurred along the Median, Lower and Major Thrust Faults. Except if there was some aseismic creep within the accretionary prism, this observation explains why the deformation at the front of the wedge was so weak. If this is correct and knowing the uncertainty on the co-seismic slip values, the Upper Thrust Fault branching upward from the interplate zone might be a candidate for transferring the co-seismic slip from the interplate zone to the sea-bottom.

Plaker et al. [31] interviewed 110 eyewitnesses, who were situated along the west coast of Sumatra, and obtained information on wave arrival times, wave heights and wave periods. Tsunami flow depths of 5 to $12 \mathrm{~m}$ along the north coast and 7 to $20 \mathrm{~m}$ along the west coast cannot be explained by the 2.8 $\mathrm{m}$ vertical displacement estimate due to slip on the plate interface alone, assuming $20 \mathrm{~m}$ maximum horizontal slip, $8^{\circ}$ fault dip, and dip-slip displacement [31]. Back tracing the recorded arrival times suggested that the source was located in the area of the Outer Arc, where Plafker et al. [32] reoccupied old bathymetric lines after the 2004 earthquake and found a recent uplift of more than 14 $\mathrm{m}$. They show that a source model consisting primarily of co-seismic uplift along a splay fault about 80 $\mathrm{km}$ long, $60^{\circ}$ dip, and $20 \mathrm{~m}$ slip that is superimposed on minor uplift $(<3 \mathrm{~m})$ due to up-dip slip on the megathrust explain the tsunami observations. Banerjee et al. [33] also considered a hypothetical splay fault approximately coincident with the location of the West Andaman Fault. When dip slip of $20 \mathrm{~m}$ is assigned to this splay fault and slip parameters are inverted, the remaining slip along the shallower portion of megathrust is only $2.9 \mathrm{~m} \pm 2.1 \mathrm{~m}$, which means that there is a kinematic discontinuity between the deeper and shallower slip on the megathrust in this area. Banerjee et al. [33] suggest that the disproportionate amount of aftershock activity deeper than $30 \mathrm{~km}$ would reflect the much greater co-seismic slip having occurred along the deeper section of the megathrust. All these arguments suggest that the portion of the Upper Thrust Fault located north of the Tuba Ridge may have ruptured during the 2004 Sumatra earthquake (Fig. 11b) as a splay fault branching on the interplate fault plane. For large size earthquakes in compressional domains, the role of splay faults has been already evidenced. For example, during the 1964 Alaskan earthquake, a thrust displacement of $8 \mathrm{~m}$ along a splay fault was observed on the Patton Bay Fault in Montague Island [34], suggesting that a substantial amount of deeper slip was transferred to the splay fault, resulting in relatively little slip on the shallower megathrust. More recently, the co-seismic slip was modeled along an inferred splay fault for the 1946 Nankai earthquake [35]. In the Nankai subduction zone, the geometry of splay faults was imaged on deep seismic reflection profiles. One of the splay faults is branching upward from the interplate zone, beneath the forearc basin, and emerges seaward of the outer arc [17], in a geological context similar to the one of our studied area. Similarly, for the 1958 earthquake on the Ecuador margin, co-seismic slip occurred along a megathrust splay fault located beneath the outer arc [36]. The associated co-seismic uplift was interpreted as the cause of the triggered tsunami. All these cases 
suggest that splay faults must be taken into account to understand the behavior of megathrust earthquakes. Surface dips of splay faults are considerably larger ( $30^{\circ}$ in the Nankai Trough) than the $10^{\circ}$ dip angle of the slab at the prism toe, increasing the resulting vertical motion of the water column and giving rise to large tsunamis (Fig. 11b). We thus conclude that during the 2004 earthquake, the co-seismic motion was transferred along a splay fault from the slab to the Upper Thrust Fault and that it was the main factor controlling the large amplitude of the tsunami.

The N004 ${ }^{\circ}$ Australia/Sunda motion being partitioned between motions perpendicular to the trench along $\mathrm{N}^{\circ} 9^{\circ}$ (example of the $26^{\text {th }}$ December 2004 earthquake) and right-lateral motions along the $\mathrm{N} 309^{\circ}$ direction, both the Sumatra Fault and the West Andaman Fault may rupture in the future as shown in Fig. 11d, giving rise to a destructive earthquake without tsunami as no significant relative vertical motion is expected.

\section{References}

[1] E.R. Engdahl, A. Villaseñor, H.R. DeShon, C.H. Thurber, Teleseismic relocation and assessment of seismicity (1918-2005) in the region of the $2004 \mathrm{Mw} 9.0$ Sumatra-Andaman and $2005 \mathrm{Mw}$ 8.6 Nias Island great earthquakes, Bull. Seism. Soc. Am. 97, doi:1785/0120050614(2007) 43-61.

[2] T. Lay, H. Kanamori, C.J. Ammon, M. Nettles, S.N. Ward, R.C. Aster, S.L. Beck, S.L. Bilek, M.R. Brudzinski, R. Butler, H.R. DeShon, G. Ekström, K. Satake, S. Sipkin, The great Sumatra-Andaman earthquake of 26 December 2004, Science 308(2005) 1127-1133.

[3] C.J. Ammon, C. Ji, H.K. Thio, D. Robinson, S. Ni, V. Hjorleifsdottir, H. Kanamori, T. Lay, S. Das, D. Helmberger, G. Ichinose, J. Polet, D. Wald, Rupture Process of the 2004 SumatraAndaman Earthquake, Science 308(2005) 1133-1139.

[4] P. Banerjee, F.F. Pollitz, R. Bürgmann, The size and duration of the Sumatra-Andaman Earthquake from far-field static offsets, Science 308(2005) 1769-1772.

[5] C. Subarya, M. Chlieh, L. Prawirodirdjo, J.-P. Avouac, Y. Bock, K. Sieh, A.J. Meltzner, D.H. Natawidjaja, R. McCaffrey, Plate-boundary deformation associated with the great SumatraAndaman earthquake, Nature 440, doi:10.1038/nature04522(2006) 46-51.

[6] C. Vigny, W.J.F. Simons, S. Abu, R. Bamphenyu, C. Satirapod, N. Choosakul, C. Subarya, A. Socquet, K. Omar, H.Z. Abidin, B.A.C. Ambrosius, Insight into the 2004 Sumatra-Andaman earthquake from GPS measurements in southeast Asia, Nature 436(2005) 201-206.

[7] M. Chlieh, J.-P. Avouac, V. Hjorleifsdottir, T.-R.A. Song, C. Ji, K. Sieh, A. Sladen, H. Hebert, L. Prawirodirdjo, Y. Bock, J. Galetzka, Coseismic slip and afterslip of the Great $M_{w} 9.15$ Sumatra-Andaman Earthquake of 2004, Bull. Seism. Soc. Am. 97, doi:1785/0120050631(2007) 152-173.

[8] M. Delescluse, N. Chamot-Rooke, Instantaneous deformation and kinematics of the IndiaAustralia plate, Geophysical Journal International 168(2007) 818-842.

[9] A. Socquet, C. Vigny, N. Chamot-Rooke, W. Simons, C. Rangin, B. Ambrosius, India and Sunda plates motion and deformation along their boundary in Myanmar determined by GPS, Journal of Geophysical Research 111, B05406, doi:10.1029/2005JB003877(2006).

[10] K. Sieh, D.H. Natawidjaja, Neotectonics of the Sumatran Fault, Indonesia, Journal of Geophysical Research 105(2000) 28,295-228,326.

[11] X. Le Pichon, Le séisme de Sumatra du 26 décembre 2004 et la subduction IndoAustralienne, Cours du Collège de France, Chaire de Géodynamique, Cours et Séminaires, année 2005-2006, http://www.cdf.u-3mrs.fr/ lepichon/(2006).

[12] J.R. Curray, Tectonics and history of the Andaman Sea region, Journal of Asian Earth Sciences 25(2005) 187-232.

[13] A. Izart, B. Mustafa Kemal, J.A. Malod, Seismic stratigraphy and subsidence evolution of the northwest Sumatra fore-arc basin, Marine Geology 12(1994) 109-124.

[14] S.C. Singh, Sumatra Aftershocks team, Sumatra earthquake research indicates why rupture popagated northward, EOS Transactions, American Geophysical Union 86(2005) 497-502.

[15] D. Fisher, D. Mosher, J.A. Austin, S.P.S. Gulick, T. Masterlark, K. Moran, Active deformation across the Sumatran forearc over the December $2004 \mathrm{M}_{\mathrm{w}} 9.2$ rupture, Geology 35(2007) 99102, doi: 110.1130/G22993A.22991.

[16] E. Araki, M. Shinohara, K. Obana, T. Yamada, Y. Kaneda, T. Kanazawa, K. Suyehiro, Aftershock distribution of the 26 December 2004 Sumatra-Andaman earthquake from ocean bottom seismographic observation, Earth, Planets and Space 58(2006) 113-119.

[17] J.-O. Park, T. Tetsuro, S. Kodaira, P.R. Cummins, Y. Kaneda, Splay fault branching along the Nankai subduction zone, Science 297(2002) 1157-1160. 
[18] W. Soh, Y.S. Djajadihardja, Y. Anantasena, K. Arai, E. Araki, S. Burhanuddin, T. Fujiwara, N.D. Hananto, K. Hirata, H. Kurnio, H. Machiyama, K.M. Badrul, C. Mueller, L. Seeber, K. Suyehiro, K. Wanatebe, Sea bottom shattered by the Sumatra-Andaman earthquake of 26 December 2004, EOS Transactions, American Geophysical Union, Supplement 86(2005) F89.

[19] C. Deplus, M. Diament, H. Hébert, B. Bertrand, S. Dominguez, J. Dubois, J. Malod, P. Patriat, B. Pontoise, J.-J. Sibilla, Direct evidence for active deformation in the eastern Indian Ocean plate, Geology 26(1998) 131-134.

[20] D.T. Sandwell, W.H.F. Smith, New global marine gravity map/grid based on stacked ERS1, Geosat and Topex altimetry, EOS Transactions, American Geophysical Union 75 (16) Spring Meet. Suppl.(1994) 321.

[21] U. Barckhausen, The Segmentation of the Subduction Zone Offshore Sumatra: Relations Between Upper and Lower Plate, EOS Trans. AGU, 87(52), Fall Meet. Suppl.(2006) Abstract U53A-0029.

[22] K. Moran, J.A. Austin, D.R. Tappin, Survey presents broad approach to tsunami studies, EOS Transactions, American Geophysical Union 86(2005) 430-432.

[23] D. Graindorge, F. Klingelhoefer, M.-G. Gutscher, J.-C. Sibuet, L. McNeill, T. Henstock, S. Dean, D. Tappin, J.-X. Dessa, S. Singh, Lower plate control of upper plate deformation at the toe of the NW Sumatra convergent margin from swath bathymetry, European Geosciences Union Meeting, Vienna, Austria, 15-20 April 2007, abstract(2007).

[24] D. Graindorge, F. Klingelhoefer, J.-C. Sibuet, L. McNeill, T. Henstock, S. Dean, M.-A. Gutscher, J.-X. Dessa, H. Permana, S. Singh, H. Leau, N. White, H. Carton, J.-A. Malod, K.G. Aryawan, A.K. Chaubey, A. Chauhan, D.R. Galih, C.J. Greenroyd, A. Laesanpura, J. Prihantono, G. Royle, U. Shankar, Interaction/links between lower and upper plate deformation at the NW Sumatran convergent margin from seafloor morphology, Earth Planet. Sci. Lett.(2007, submitted).

[25] H. Carton, S.C. Singh, N. Hananto, D. Hartoyo, A. Chauhan, P. Tapponnier, N. White, T. Bunting, P. Christie, H. Lubis, J. Martin, Schlumberger seismic vessel Geco Searcher provides unprecedented images of the Great Sumatra-Andaman earthquake megathrust rupture plane, Eos Trans. AGU, 87(52), Fall Meet. Suppl., Abstract U53A-0026(2006).

[26] C. Gaedicke, D. Franke, S. Ladage, D. Tappin, B. Baranov, U. Barckhausen, K. Berglar, G. Delisle, Y. Djajadihardja, I. Heyde, R. Lutz, K. Khafid, C. Mueller, K. Nur Adi, J. Park, L. Seeber, S. Neben, E. Triarso, Imaging the rupture areas of the Giant Northern Sumatra Earthquakes: A multidisciplinary geophysical experiment, Eos Trans. AGU, 87(52), Fall Meet. Suppl., Abstract U52A-01(2006).

[27] T.J. Henstock, L. McNeill, D.R. Tappin, Seafloor morphology of the Sumatran subduction zone: Surface rupture during megathrust earthquakes?, Geology 34(2006) 485-488.

[28] S. Sultan, A. Cattaneo, J.-C. Sibuet, J.-L. Schneider, Sumatra Aftershocks team, Evidence from piezometer monitoring of in situ excess pore pressure and sediment deformation generated during the December 26, 2004 Great Sumatra-Andaman Earthquake, in: M. Canals, (Ed), Slope instabilities, International Journal of Earth Sciences, Special Issue, 2007, submitted.

[29] Y. Auffret, P. Pelleau, F. Klingelhoefer, L. Geli, J. Crozon, J.-Y. Lin, J.-C. Sibuet, MicrOBS: A new generation of ocean bottom seismometer, first break 22(2004) 41-47.

[30] K. Tsumara, Determination of earthquake magnitude from duration of oscillation, Jishin (in Japanese) 2(1967) 30-40.

[31] G. Plafker, L.S. Cluff, X. Lloyd, S.P. Nishenko, Y. Stuart, D. Syahrial, The cataclysmic 2004 tsunami on NW Sumatra - Preliminary evidence for a near-field secondary source along the Western Aceh Basin, Seism. Soc. Am., Annual meeting, San Francisco, CA, April, 2006, Abstract(2006).

[32] G. Plafker, S.N. Ward, S.P. Nishenko, L.S. Cluff, J. Coonrad, D. Syahrial, Evidence for a secondary tectonic source for the cataclysmic tsunami of 12/26/2004 on NW Sumatra, Seism. Soc. Am., Annual meeting, Kona, Hawaii, April 11-13, 2007, Abstract(2007).

[33] P. Banerjee, F.F. Pollitz, B. Nagarajan, R. Bürgmann, Coseismic slip distributions of the 26 December 2004 Sumatra-Andaman and 28 March 2005 Nias earthquakes from GPS static offsets, Bull. Seism. Soc. Am. 97, doi: 10.1785/0120050609(2007) 86-102.

[34] G. Plafker, Alaskan earthquake of 1964 and Chilean earthquake of 1960: implications for arc tectonics, Journal of Geophysical Research 77(1972) 901-923.

[35] P.R. Cummins, Y. Kaneda, Possible splay fault slip during the 1946 Nankai earthquake, Geophysical Research Letters 27(2000) 2725-2728. 
[36] J.-Y. Collot, B. Marcaillou, F. Sage, F. Michaud, W. Agudelo, P. Charvis, D. Graindorge, M.-A. Gutscher, G. Spence, Are rupture zone limits of great subduction earthquakes controlled by upper plate structures? Evidence from multichannel seismic reflection data acquired across the northern Ecuador-southwest Colombia margin, Journal of Geophysical Research 109, B11103, doi.1029/2004JB003060(2004).

[37] S.-K. Hsu, J.-C. Sibuet, Earthquake off Japan could generate strong tsunami, Eos 86(2005) 169-170.

\section{Acknowledgments:}

We thank the Presidents of Ifremer and Institute Paul-Emile Victor (IPEV) for their constant supports and encouragements to achieve on a short notice the "Sumatra Aftershocks" cruise onboard the R/V Marion Dufresne. We thank Yvon Balut (IPEV), Pierre Cochonat (Ifremer), John Ludden (Institut National des Sciences de l'Univers) and Jean-Paul Montagner (Direction Générale de la Recherche et de I'Innovation) for their support. The Indonesian Agency for the Assessment and Application of Technology (BPPT) is greatly acknowledged for its help and support during the planning stage of the cruise. The French Hydrographic Service (SHOM) helps to validate swath-bathymetric data. Bernard Ollivier (IPEV) and his technical team are particularly acknowledged for their dedicated work at sea. We thank Bob Engdahl for providing his relocated teleseismic events in the Sumatra region. We thank Jo Curray, Jamie Austin and an anonymous reviewer for their careful and constructive reviews. Financial supports were provided by the Agence Nationale de la Recherche (ANR), the Délégation Inter-ministérielle pour le Tsunami (DIPT), Ifremer and IPEV. 

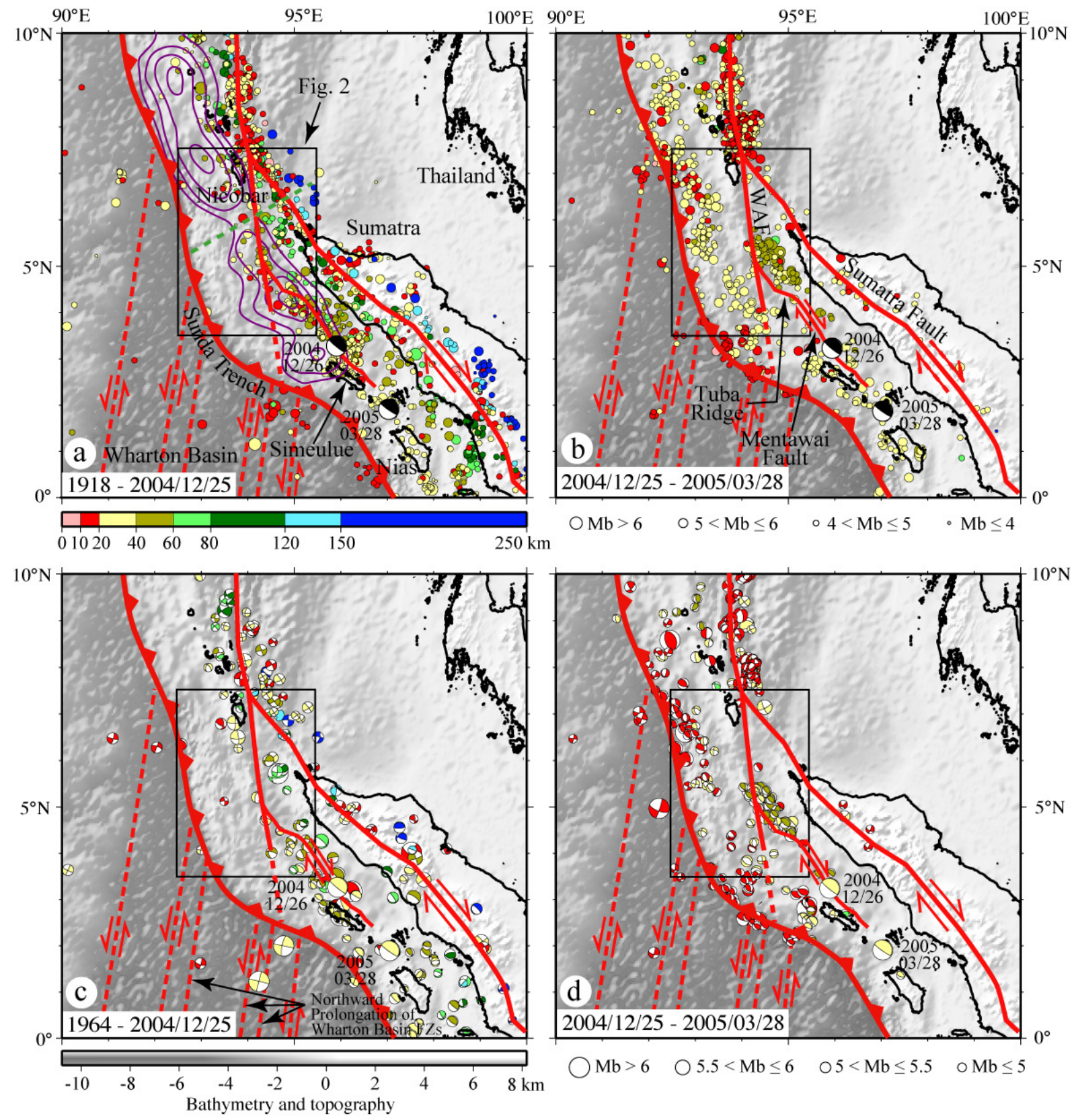

Sibuet et al., Figure 1

Figure 1: a) Seismicity in the Sumatra-Andaman region relocated [1] and color classified by depth from 1918 through 25 December 2004. The size of hypocenters is function of the magnitude $\mathrm{Mb}$. The two focal mechanisms in black correspond to the Sumatra and Nias events. Bathymetry and topography in grey [20]. The red line with triangles is the trench location and red lines are tectonic features from Hsu and Sibuet [37]. Dashed lines are oceanic fracture zones. Three of them, identified in the central Wharton Basin [19] were extended northward by using gravity [20] and magnetic [21] data. The other suggested fracture zones were drawn on the basis of gravity and magnetic data alone. Co-seismic slip contours every $5 \mathrm{~m}$ in purple from Chlieh et al. [7] show different geographic distributions in the Nicobar and Sumatra sectors roughly separated by a dashed green line. b) Aftershock seismicity [1] between the dates of the Sumatra and Nias events. Legend as in Fig. 1a. c) Focal mechanisms from the Harvard catalog color classified by depth from 1964 through 25 December 2004. Beach balls in lower hemisphere projection are plotted at the location of the relocated earthquakes of Engdahl et al. [1]. Legend as in Fig. 1a. d) Aftershocks focal mechanisms from the Harvard catalog color classified by depth from 25 December 2004 through 28 March 2005 at the location of relocated earthquakes [1]. 


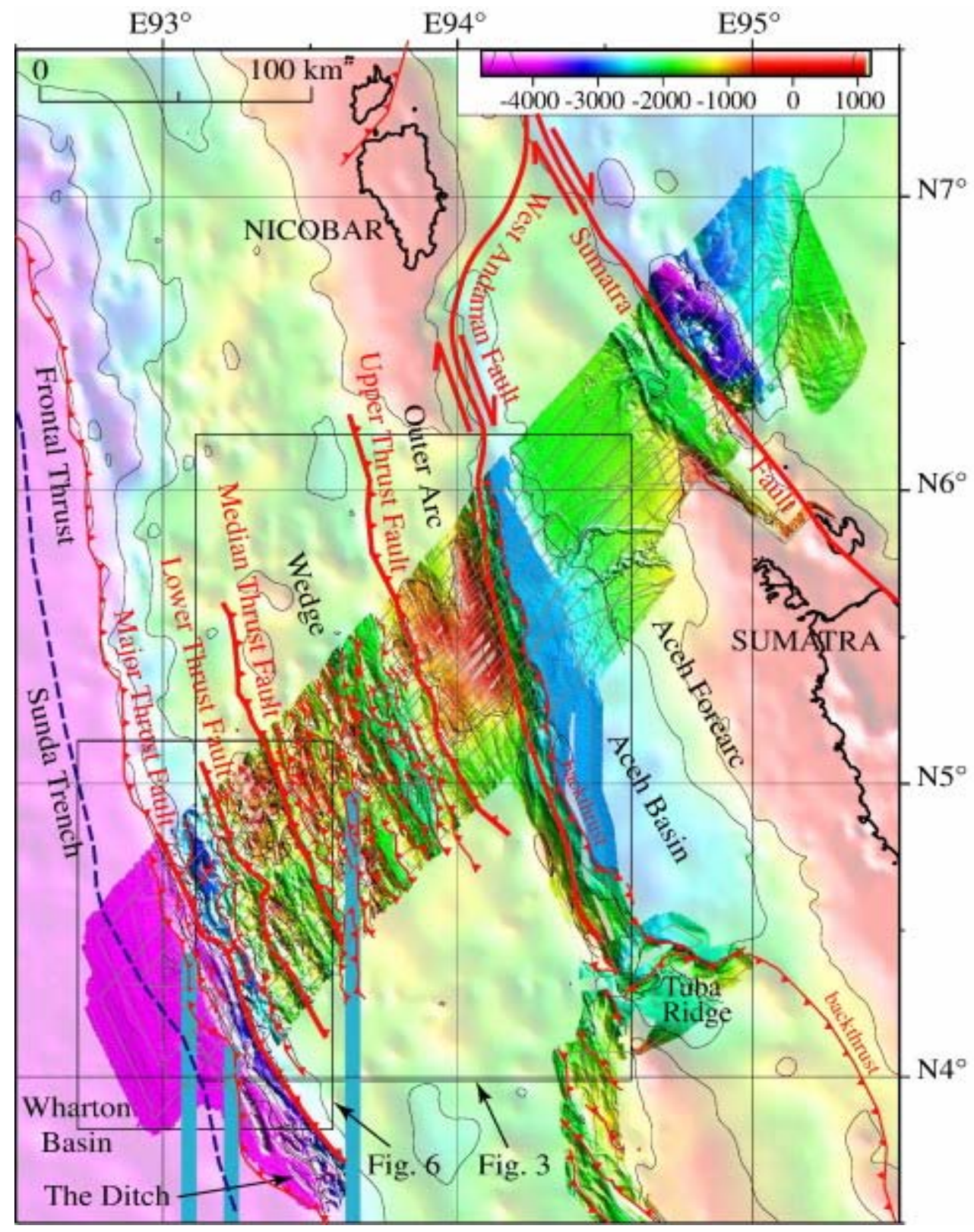

Figure 2: Swath-bathymetric data collected along a $370 \times 75 \mathrm{~km}$ stripe located southeast of the India-Indonesia water limit over the regional bathymetry [20]. Light from the southwest. The thin gray lines are tracklines along which swath bathymetric and $3.5 \mathrm{kHz}$ data were continuously collected. Main structural elements in red. Lines with triangles are thrust faults. Thick continuous red lines with triangles are main thrust faults determined from swath-bathymetric and $3.5 \mathrm{kHz}$ data. The solid N-S trending blue lines are the locations of N-S fracture zones of the Wharton Basin and their associated N-S trending valleys in the wedge. 


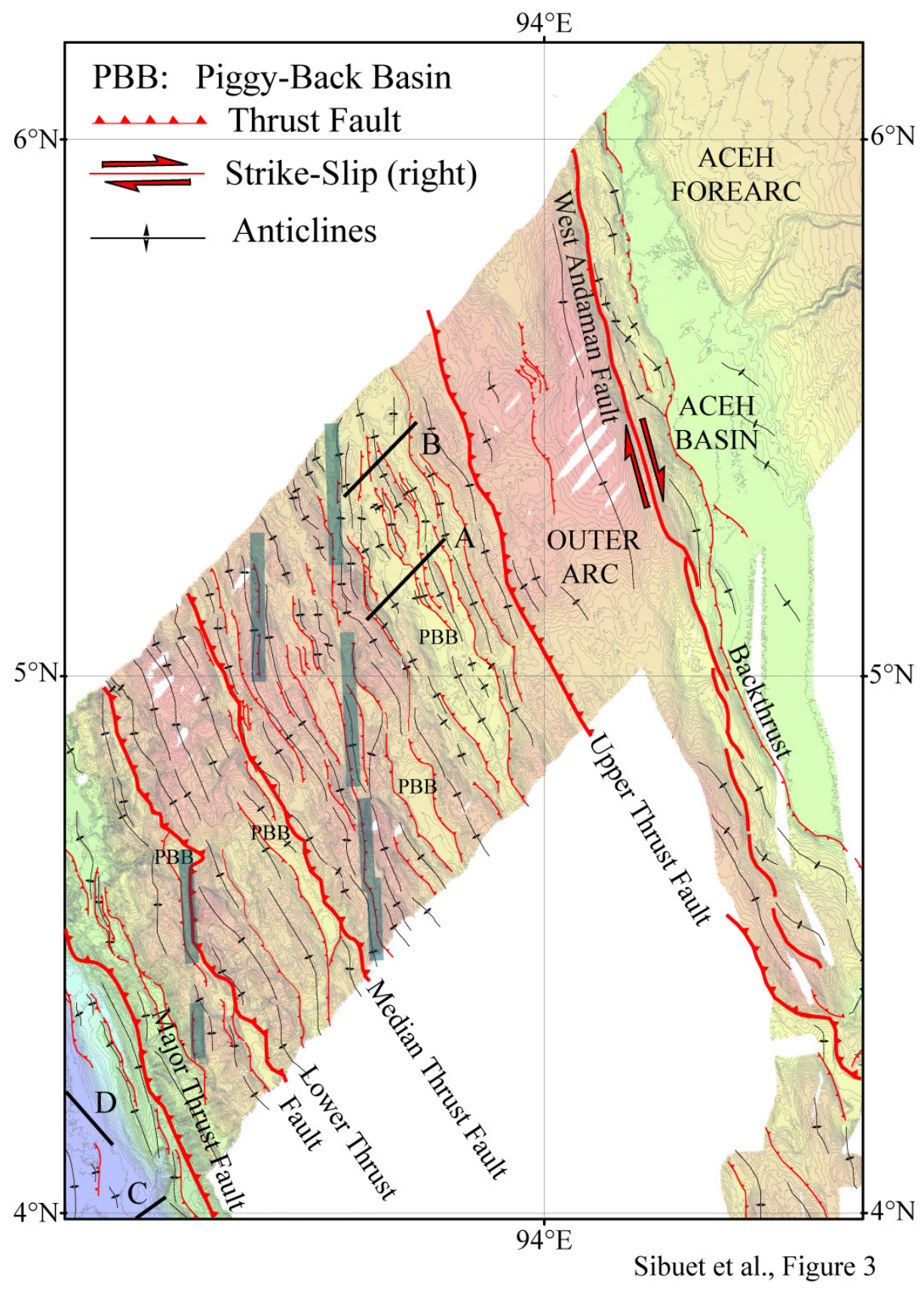

Figure 3: Detailed structural interpretation of the upper part of the accretionary wedge located southwest of the Outer Arc. Blue grayish lines, N-S trending valleys of the wedge; thick continuous red lines with triangles, thrust faults as in Fig. 2. Light from the southwest. A, B, C and $\mathrm{D}$ are $3.5 \mathrm{kHz}$ profiles shown in Figs 4, 5, 8 and 9, respectively. 

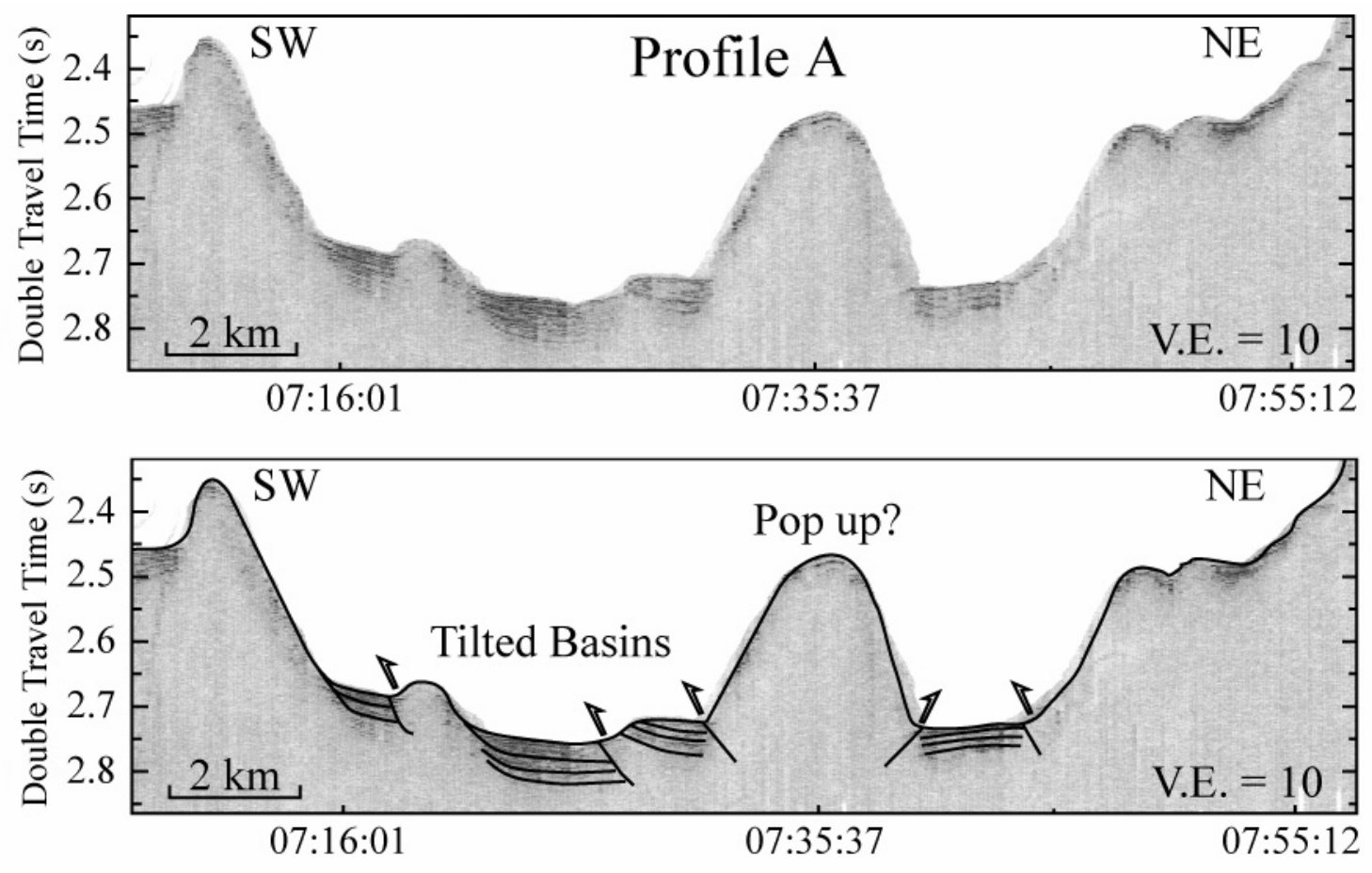

Sibuet et al., Figure 4

Figure 4: $3.5 \mathrm{kHz}$ Profile A located in Fig. 3 across a possible pop up feature and small elongated tilted basins observed within a piggy-back basin. 

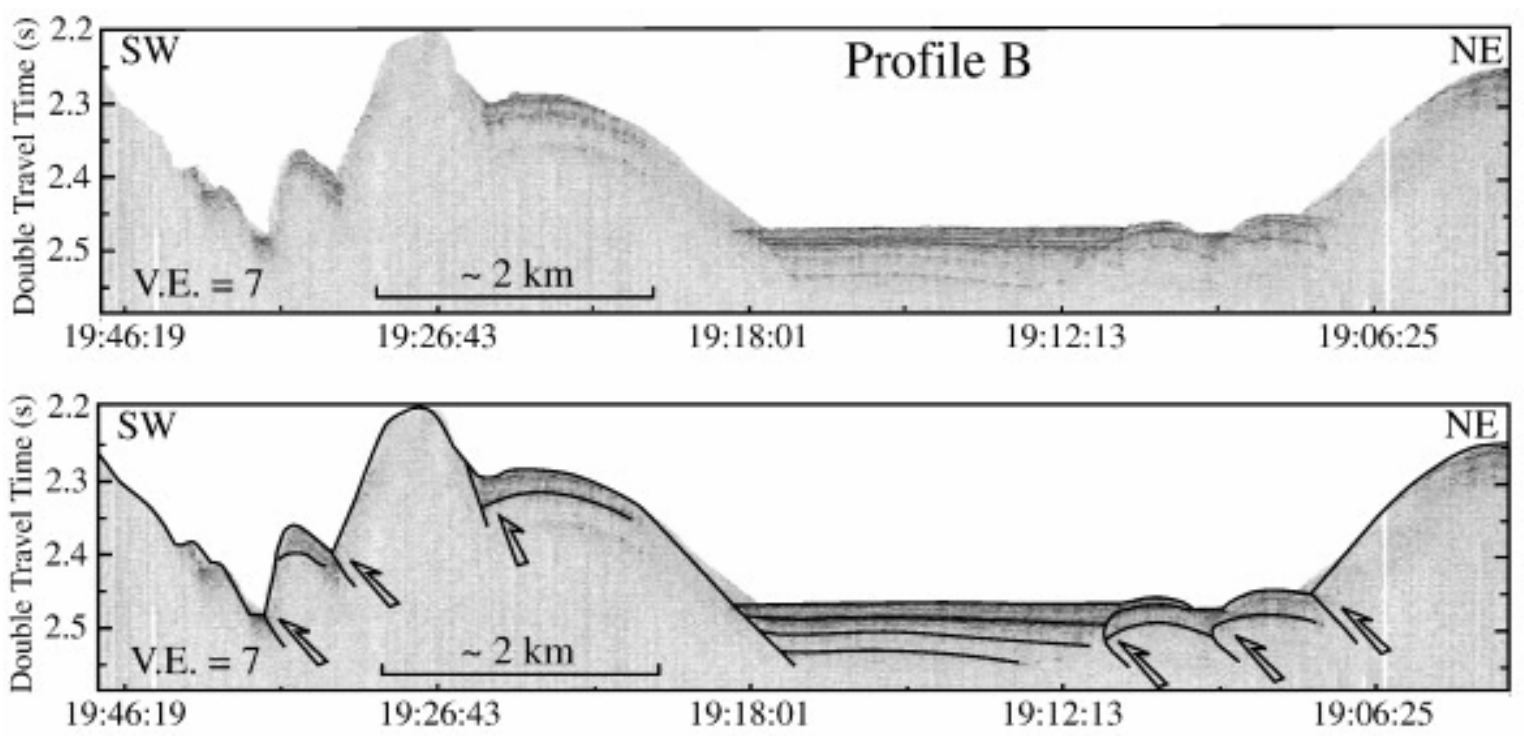

Figure 5: $3.5 \mathrm{kHz}$ Profile B located in Fig. 3 across the same piggy-back basin than in Fig. 4, with numerous seaward vergence thrust faults showing signs of recent tectonic activity. 


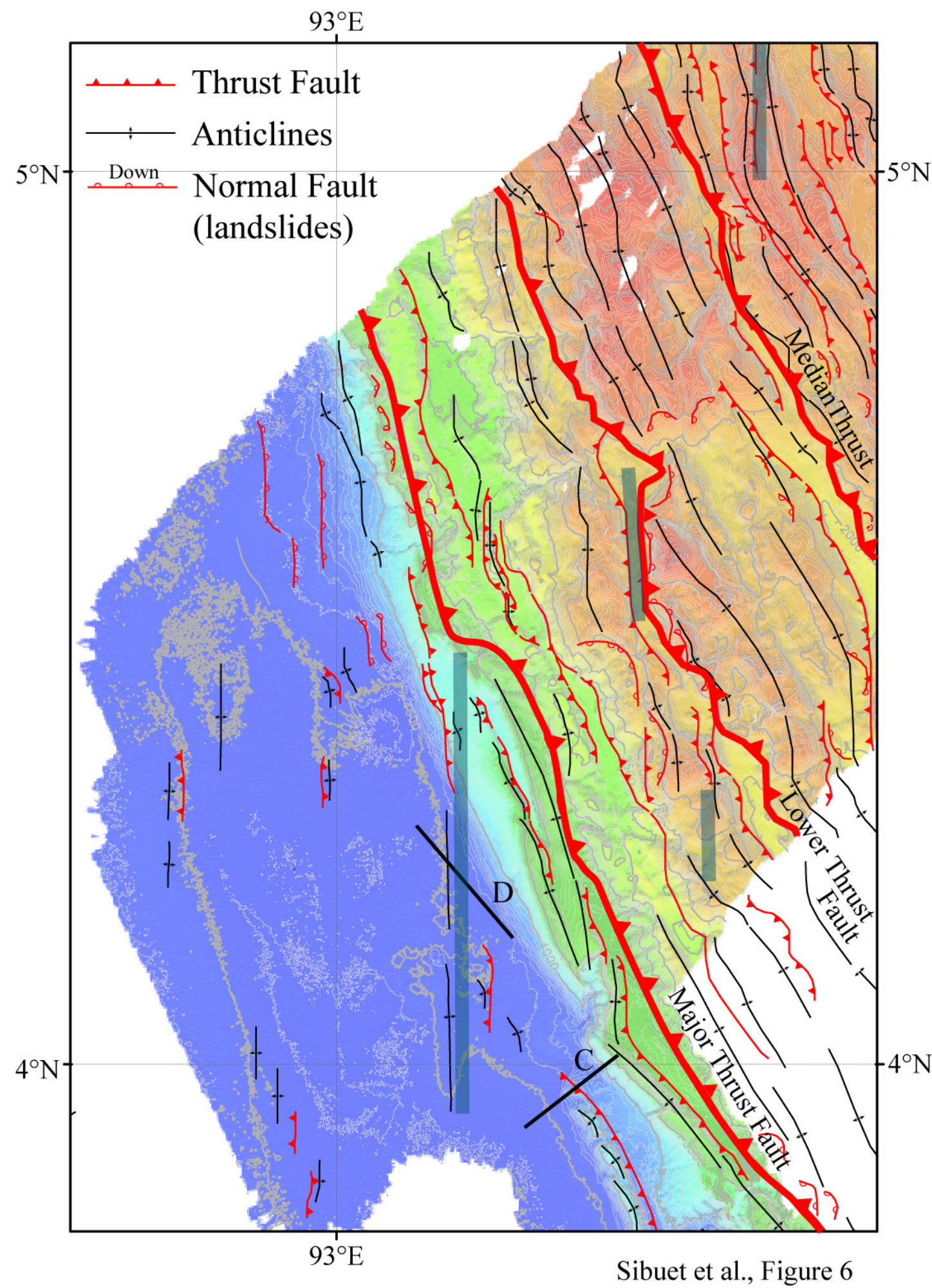

Figure 6: Detailed structural interpretation close to the deformation front. Blue grayish lines, N-S trending valleys of the wedge; thick continuous red lines with triangles, thrust faults as in Fig. 2. Light from the southwest. $C$ and $D$ are $3.5 \mathrm{kHz}$ profiles shown in Figs 8 and 9, respectively. 


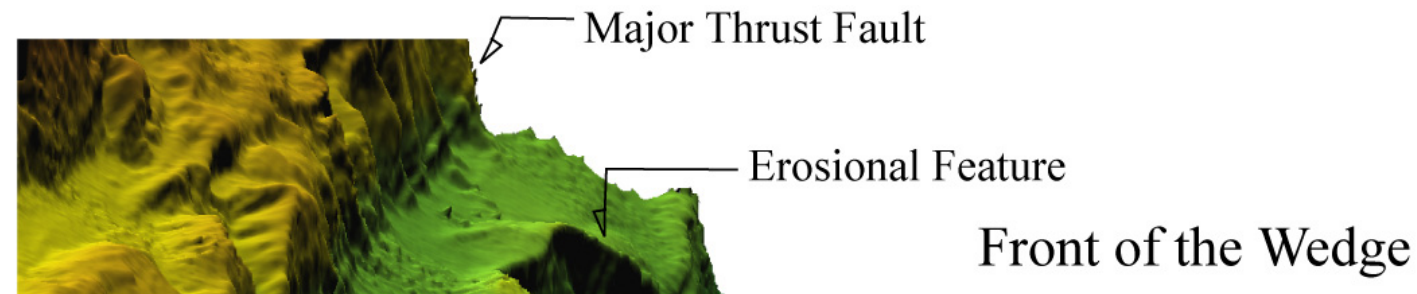

Land Slide Partially

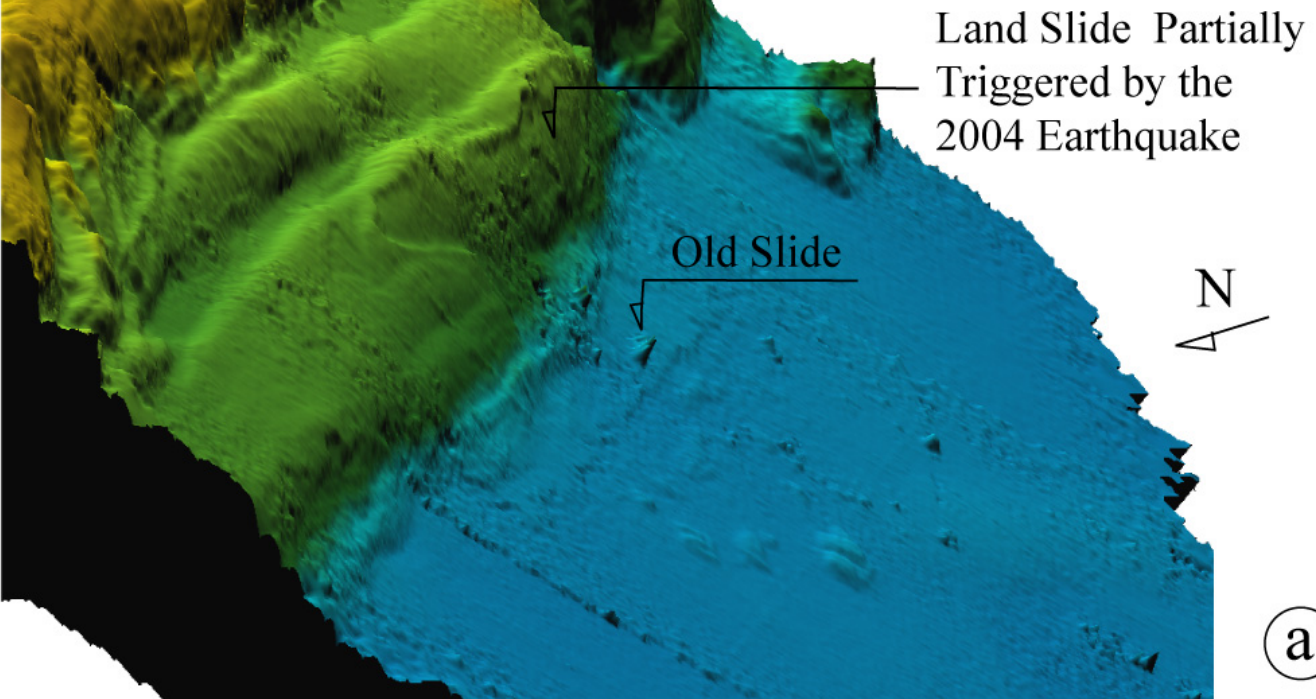

a

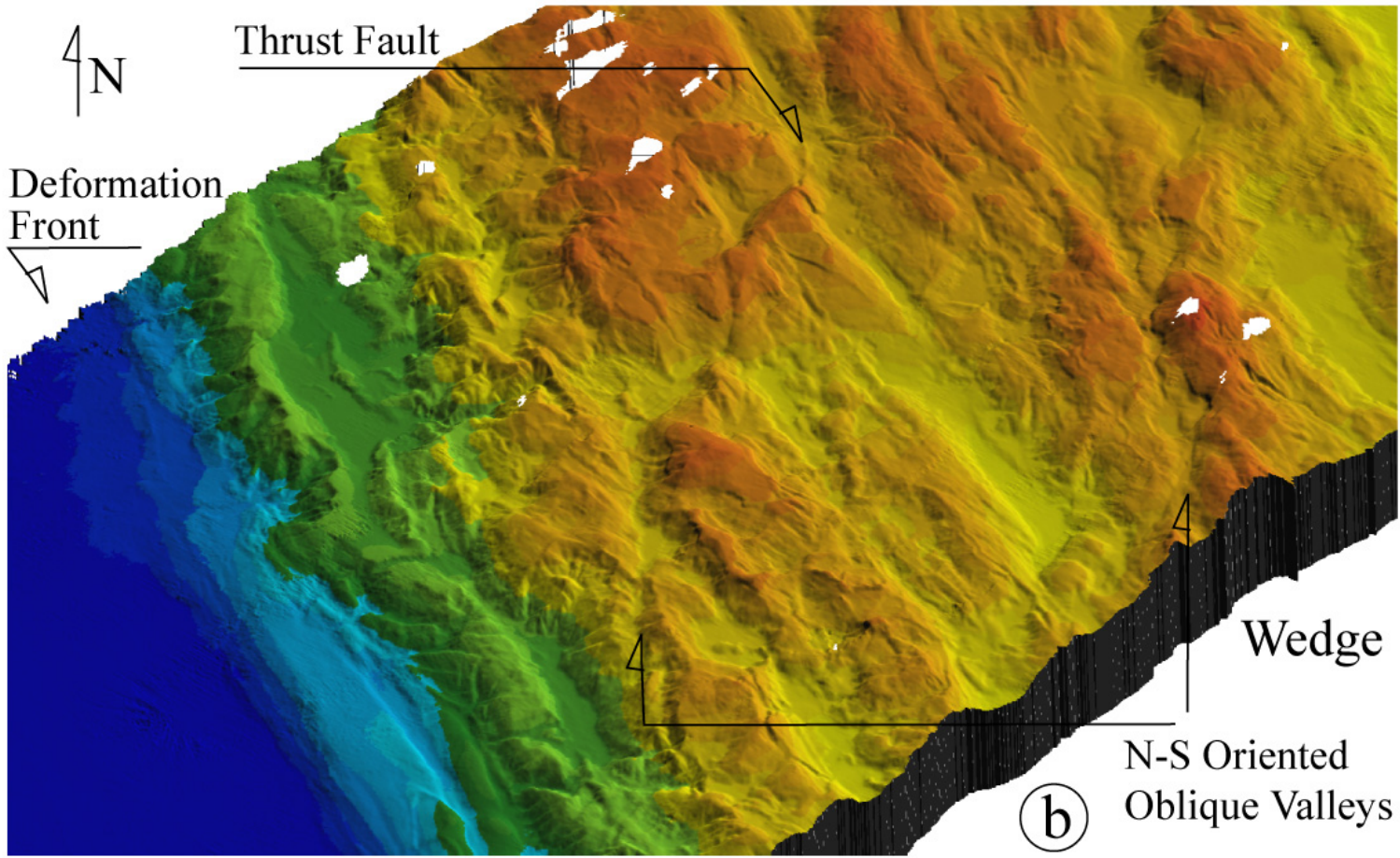

Sibuet et al., Figure 7

Figure 7: Block diagrams of a) the toe of the accretionary wedge, with a minor landslide located close to the trench and the Major Thrust Fault located at the base of the eroded wall (festoon); b) the main part of the wedge with the well-imaged N-S valleys linked to N-S fracture zone features of the lower plate. 

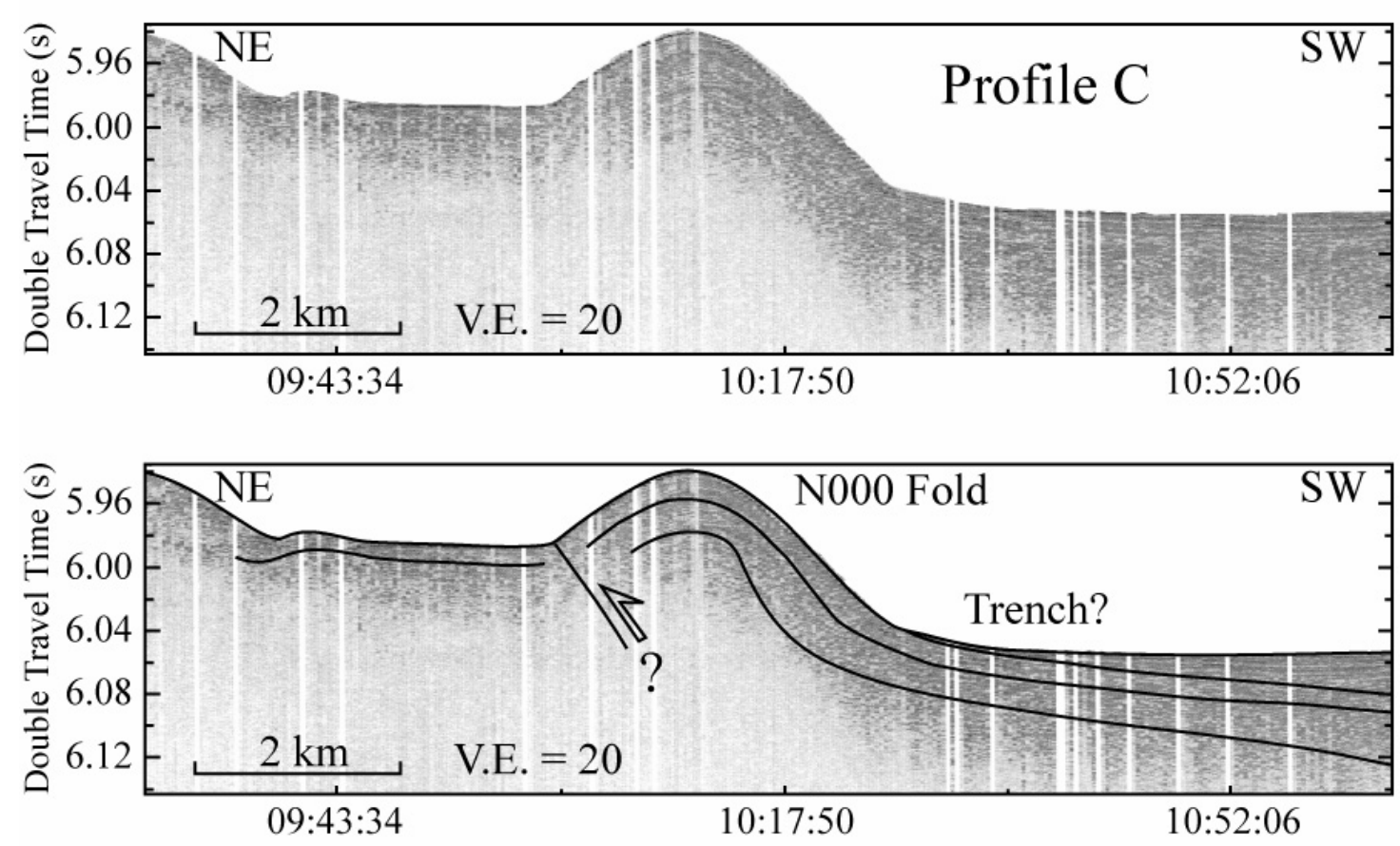

Sibuet et al., Figure 8

Figure 8: $3.5 \mathrm{kHz}$ Profile $\mathrm{C}$ located in Figs. 3 and 6 across a N-S oriented fold with a possible EW compressive component. 

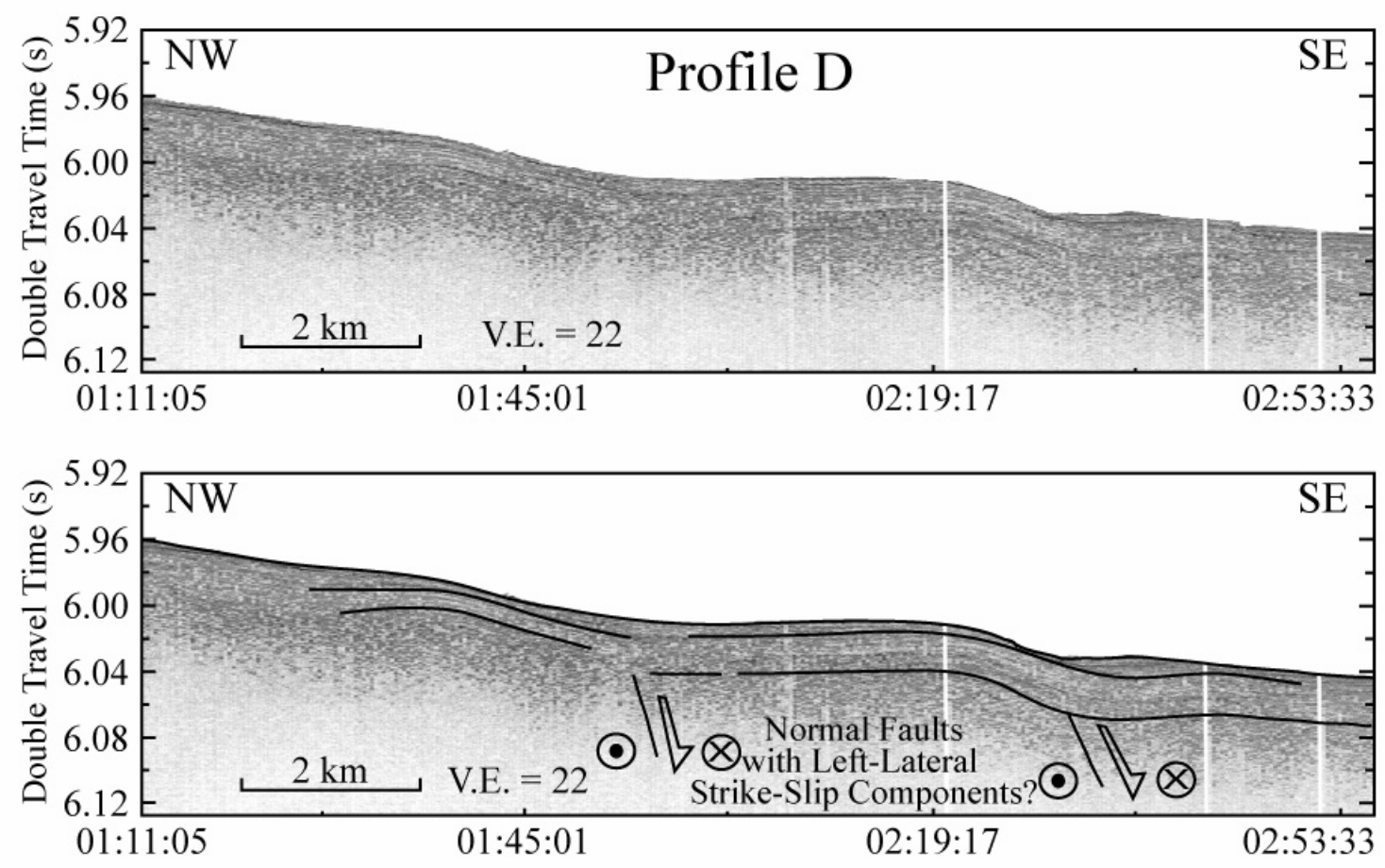

Sibuet et al., Figure 9

Figure 9: $3.5 \mathrm{kHz}$ Profile D located in Figs. 3 and 6 across potential N-S normal faults with leftlateral strike slip components. 


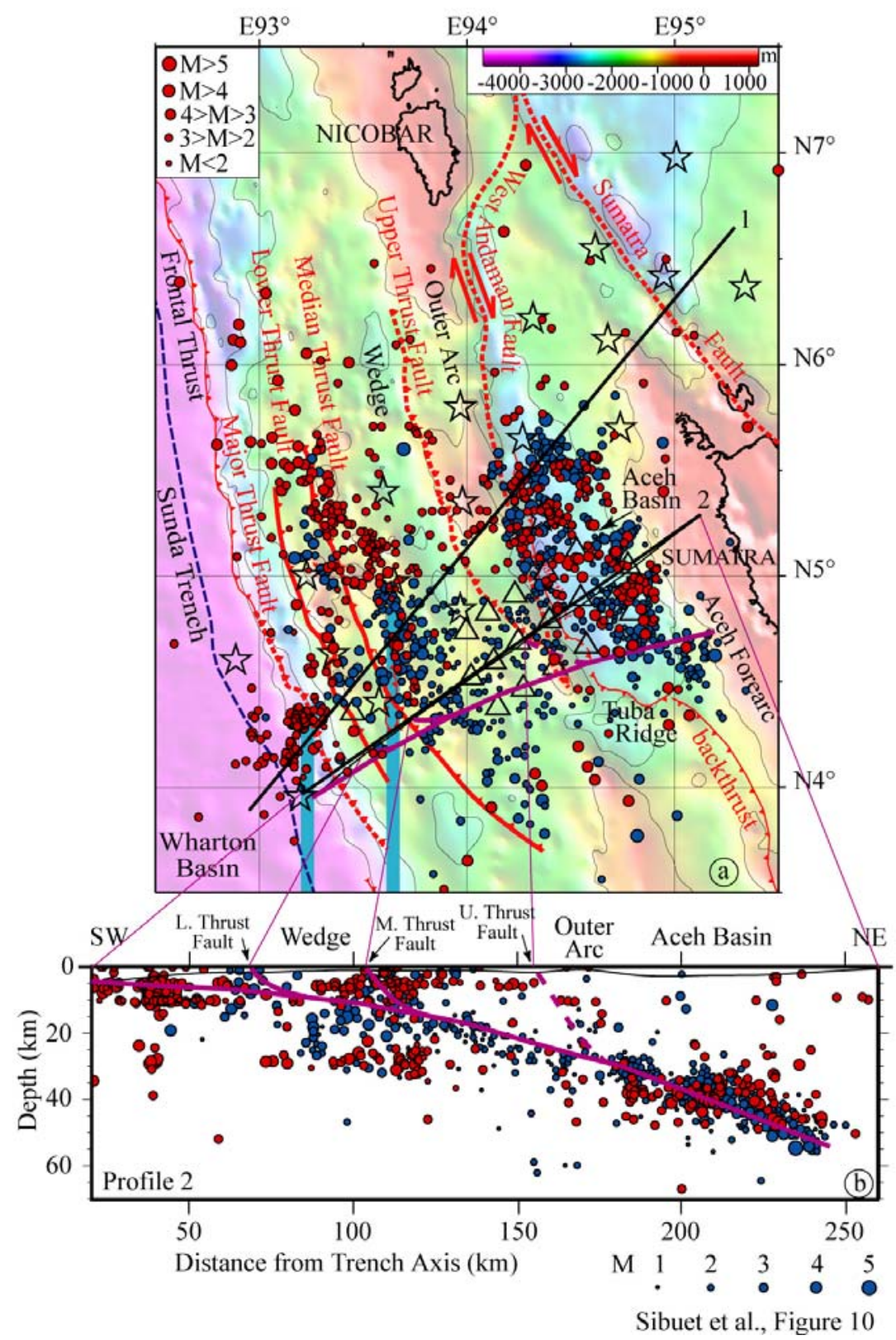

Figure 10: a) Aftershock determinations from the two Japanese and French networks of seismometers. In blue, aftershocks determined during 10 days of the recording period (20 February - 13 March 2005) by Araki et al. [16] using 17 seismometers (triangles). In red, 665 aftershocks determined from our survey using 20 seismometers (stars) from 22 July 2005 to 3 August 2005. Magnitudes of earthquakes scaled in the upper left part of the figure. Large solid and dashed lines with triangles are post-seismic active thrust faults (Lower and Median Thrust Faults) and non-active post-seismic features, respectively. Thick blue lines are the lower plate $\mathrm{N}-\mathrm{S}$ fracture zones and their prolongations below the lower part of the wedge. Note the presence of a swarm of 186 events located at the northern extremity of the $93.2^{\circ} \mathrm{E}$ fracture zone and of a large number of events along the northern extremity of the $93.6^{\circ} \mathrm{E}$ fracture zone, highlighting the shift of seismicity along the Median Thrust Fault from S-E of it in February 2005 to N-W of it in August 2005. The projected synthetic profile 2 shows in purple the slab and active thrust faults determined from the hypocenters distribution. b) Seismicity along Profile 2 in function of the distance to the trench. Only hypocenters located inside the Japanese [16] and French (498 events) networks are shown in blue and red, respectively. In purple, slab and thrust faults deduced from the distribution of hypocenters. Note the presence of lower plate events in the $40-60 \mathrm{~km}$ and $90-130 \mathrm{~km}$ stripes, suggesting the re-activation of lower plate fracture zones. 

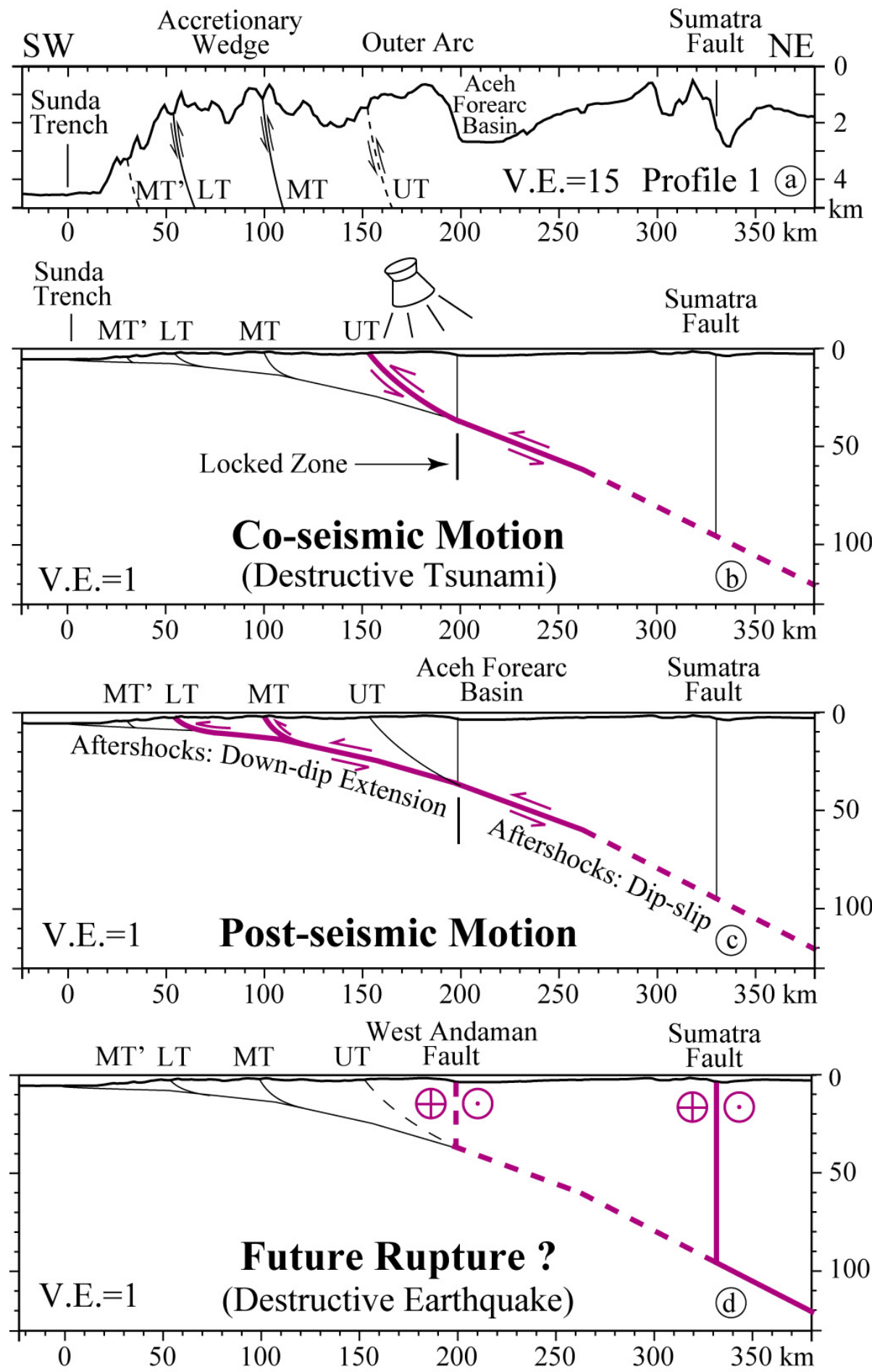

Sibuet et al., Figure 11

Figure 11: Sketch of co- and post-seismic motions of the Great Sumatra-Andaman Earthquake. a) Topographic crosssection along Profile 1 located in Figure 10a. Identified active and inactive thrust faults corresponding to those of Figure 10 in continuous and dashed black lines, respectively. MT', Major Thrust Fault; LT, Lower Thrust Fault; MT, Median Thrust Fault; UT, Upper Thrust Fault. b) Same cross-section without vertical exaggeration with co-seismic motion along the slab and the Upper Thrust Fault in purple. Inactive thrust faults and features in thin black lines. c) In purple, postseismic motion along the slab and the Lower and Median Thrust Faults determined from the distribution of aftershocks without vertical exaggeration. Inactive thrust faults and features in thin black lines. d) Sketch of potential shear-type ruptures along the West-Andaman or Sumatra Faults, which might give rise to destructive earthquake damages in the future. 